\title{
Introduction to "Glycometabolome"
}

\author{
“糖鎖代謝学”ノススメ \\ Suzuki, Tadashi \\ Glycometabolome Team, Systems Glycobiology Group, RIKEN Advanced Science Institute and \\ CREST (Core Research for Evolutionary Science and Technology), \\ Japan Science and Technology Agency (JST), Japan \\ Glycometabolome Team, RIKEN Advanced Science Institute (ASI) \\ 2-1 Hirosawa, Wako, Saitama 351-0198, JAPAN \\ Tel: +81-48-467-9628, Fax: +81-48-467-9626, E-mail: tsuzuki_gm@riken.jp
}

(Received May 18, 2009, accepted on July 31, 2009)

Key Words: N-glycans, PNGase, lysosome, cytosol, catabolism

\begin{abstract}
$\mathrm{N}$-glycosylation is now recognized as one of the most important modification reactions in eukaryotic cells, and it has been demonstrated that $N$-glycans on glycoproteins have crucial roles on their physicochemical properties such as solubility or stability of proteins, as well as their physiological properties such as bioactivity or intra- and intercellular trafficking. Explosive progress of glycobiology during the past decades unveiled most, if not all, of the biosynthetic pathway for $N$-glycans. On the other hand, how the $N$-glycans are catabolized in cells is relatively unexplored even in this "post-genome" era. Here I would like to outline what is known and what should be clarified regarding the catabolic pathway of $N$ glycans.
\end{abstract}

\section{A. Introduction}

Peptide: $N$-glycanase (PNGase) hydrolyzes the $\beta$ aspartylglycosylamine bond of $N$-linked glycoproteins/ glycopeptides. This enzyme activity was first detected in almond by Dr. Noriko Takahashi (1). Therefore PNGase is yet another example of great contribution to glycobiology from Japanese scientists. Because PNGase removes glycan moieties from glycoproteins under conditions much milder than those required for chemical hydrolysis of glycans, the enzymes from plant (1) and bacteria (2) origins have been widely used as a powerful tool reagent for structure/function studies of $N$-linked glycans on glycoproteins. On the other hand, the physiological importance of PNGase itself has not been rigorously investigated until recently.

The presence of PNGase activity in animals was first reported by Seko et al. in embryos of Medaka fish (3).

\section{要 旨}

$\mathrm{N}$ 型糖鎖の付加（ $N$-glycosylation）は，今や真核細胞に とって最も重要な翻訳後修飾機構の一つとして認識されてき ている。実際，糖タンパク質上の $\mathrm{N}$ 型糖鎖がタンパク質の可 溶性や熱安定性といった物理化学的性質に加え, 生理活性や 細胞内, あるいは細胞間の輸送に影響を与える例は枚挙に㗇 がない。最近の糖鎖生物学の急速な発展によって, N 型糖鎖 の生合成経路はその殆どが解明されているといってもよい が，一方で $\mathrm{N}$ 型糖鎖がぞのように代謝されるのか，というこ とに関してはこの“ポストゲノム”と称される今に至っても 不明な点だらけ，といった状態である。本総説では $\mathrm{N}$ 型糖鎖 の代謝について, これまで分っていること, そして今後明ら かにすべき事柄について，私見を交えて概観したい。

\section{A. はじめに}

ペプチド：N-グリカナーゼ (PNGase) は糖タンパク質, あるいは糖ぺプチドの根元の糖アミド結合を切断する加水分 解酵素である。本酵素活性は高橋によってアーモンド種子に 初めて見出された，日本発の酵素である(1)。PNGaseによる 糖鎖脱離は, 糖タンパク質から糖鎖部分を外す際, 化学的な 処理に比べて穏和な条件で脱離することが出来るため, 植物 およびバクテリア由来 $(2)$ の本酵素は $\mathrm{N}$ 型糖鎖の構造, および 機能研究に抢ける有用な試薬として広く用いられてきた。一 方でその酵素自体の生理機能については, 長い間研究の対象 とされていなかった。

動物細胞における最初の PNGase 活性は, 瀬古らによっ てメダカ肧に同定された (3)。この酵素は酸性を至適 $\mathrm{pH}$ に持 つもので, これまでのところこの酸性酵素と類似の活性は哺 乳動物には見つかっていない。一方で, 細胞質に存在する 
This fish-derived PNGase was active at acidic $\mathrm{pH}$, and so far the similar activity has not been detected in mammalian cells. The cytoplasmic PNGase in mammalian cells were first detected in various mammalian-derived cultured cells $(4,5)$. The cytoplasmic PNGase was implicated in the degradation process of misfolded glycoproteins in the endoplasmic reticulum (ER). For details of structures/functions of the cytoplasmic PNGase, the readers are directed to our recent review articles (6-11). This article would rather serve as an essay than a review article, and I will briefly overview the current knowledge of degradation pathway for $N$-glycans and address the concept and future perspective of "glycometabolome", which I believe we need to establish in an urgent fashion.

\section{B. Catabolism of $N$-glycans (1); Lysosomal degradation}

Our textbook-knowledge of degradation pathway for $\mathrm{N}$-glycans is almost completely restricted to the process in the lysosomes (Fig. 1). There are a couple of excellent reviews available for details of this subject $(12,13)$. In general, enzymes related to degradation of glycans have been well studied in relation to the genetic diseases, and it is well known that defect of these enzymes will cause vari-
PNGase については, 哺乳動物培養細胞中に初めて活性が検 出された $(4,5)$ 。本酵素は小胞体において正しい高次構造を獲 得できない糖タンパク質の分解系に関わっていることが示唆 されてきているが，その詳細については我々の総説を参考に していただければ幸いである(6-11)。本総説では，糖タンパ ク質の $\mathrm{N}$ 型糖鎖の分解機構に絞って, これまで分かっている ことを（私見を交えて）読反物的に概観させていただくこと にする。
教科書的には, $\mathrm{N}$ 型糖鎖の分解機構に関しての記述はほ ぼリソソーム内の現象に限定される（図 1)。詳細は他の総説 に譲るが $(12,13)$, 糖鎖の分解に関する酵素群は, リソソーム 病との関連で非常によく調べられて抢り，その欠損が様々な 病態を引き起こすことは周知の通りである。なお，リソソー ムに打ける $\mathrm{N}$ 型糖鎖の分解に関わる酵素のうち, キトビアー

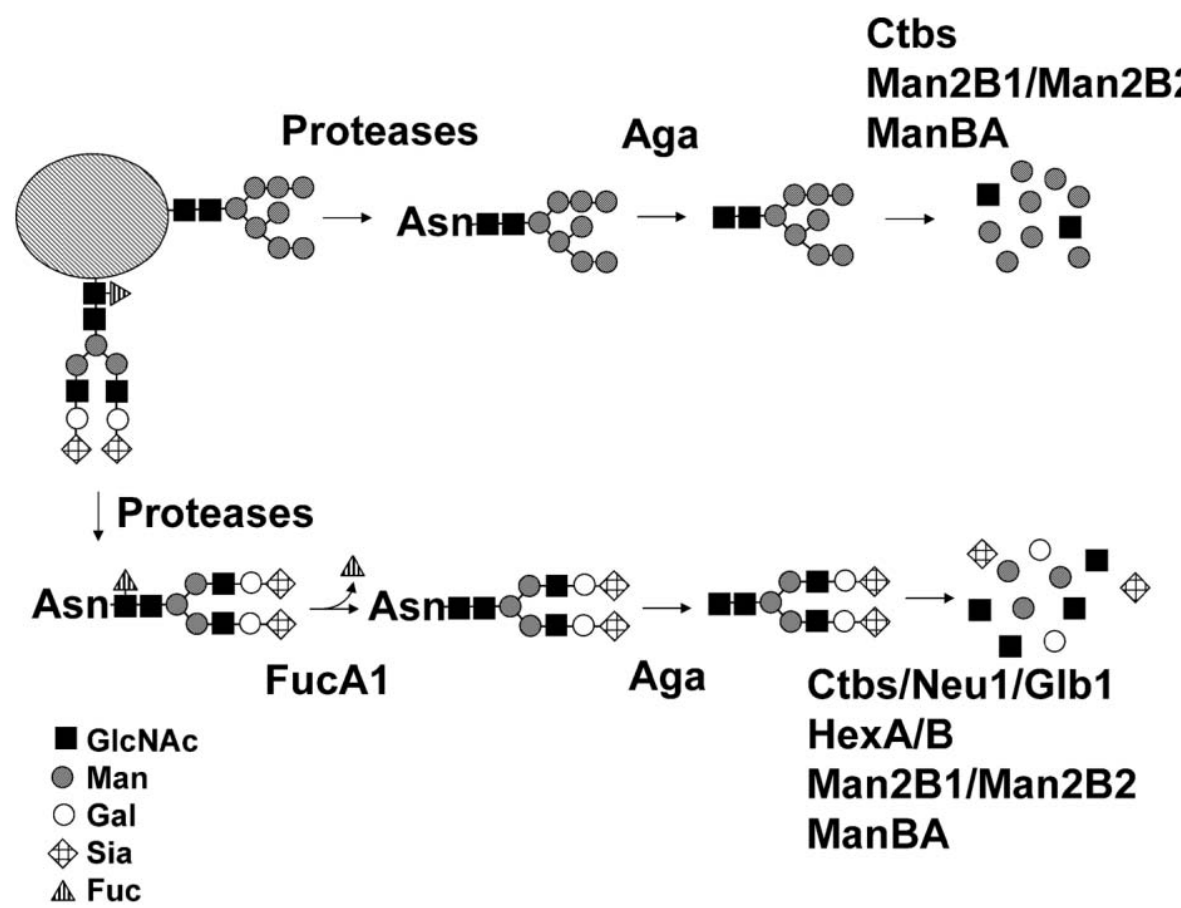

Fig. 1. Degradation of a model $N$-glycoprotein in the lysosomes of human cells. Note that this scheme may not be applicable for cells derived from different organisms. After proteolytic degradation by various exo- and endoproteases, glycan part was degraded in a bidirectional manner $(12,13)$. Aga, aspartylglucosaminidase; Ctbs, chitobiase; FucA1, $\alpha$ fucosidase; Neu1, $\alpha$-neuraminidase; Glb1, $\beta$-galactosidase; HexA/B, $\beta$-hexosaminidase; Man2B1, Man2B2, $\alpha$-mannosidase; ManBA, $\beta$-mannosidase. 
ous pathological conditions collectively called "lysosomal storage diseases". It is important to note that enzymes such as chitobiase or Man2B2 $\alpha$-mannosidase (in Fig. 1) do not exist in some mammalian species (14-16). Therefore we should keep in mind that the process depicted in Fig. 1 is the case for human cells, and by no means applicable to all mammals, let aside other non-mammalian cells.

\section{Catabolism of $N$-glycans (2); Non-lysosomal degrada- tion}

This is the process yet to be explored, compared with the lysosomal counterpart. The readers are directed to our recent reviews for the detail of current knowledge about this process $(9,11,17,18)$, but the bottom line here is that we do not have information other than the cytoplasmic PNGase (19), endo- $\beta$ - $N$-acetylglucosaminidase (ENGase) (20), and the cytosolic $\alpha$-mannosidase (Man2C1) (21) with respect to the molecular mechanisms involved in this process (Fig. 2). In this connection, I also would like to encourage the readers to refer to our most recent review on "Glycobiology in the cytosol", where many attractive questions still remain to be investigated
ゼやMan2B2 と呼ばれるマンノシダーゼなどは, 哺乳動物の 種によって存在しないものあるようであり(14-16)，ここに示 された図はあくまでヒトに抢ける経路であり哺乳動物でも種 が違えば必ずしもこの図通りでない点は注意されたい。

C. $N$ 型糖鎖の分解(2) : リソソーム以外での分解

リソソームに打ける分解に比べて，まだ解析が進んでい ないのがリソソームによらない（非リソソーム）糖鎖の分解 である。これまでの知見はいくつかの総説で詳述しているの でそちらを参考にしていただければ幸いであるが $(9,11,17,18)$, 現在のところ PNGase (19), エンド- $\beta-N$-アセ チルグルコサミニダーゼ（ENGase）（20），そして細胞質マン ノシダーゼ（Man2C1）（21）以外の分子機構については全くと いってよいほど情報がない（図 2)。ちなみに，非リソソーム の糖鎖代謝で中心的な役割を果たす細胞質には糖鎖生物学の 中でも興味ある未解決な問題が多く残されているのだが, 最 近の総説で紹介させていただいたので是非参照されたい

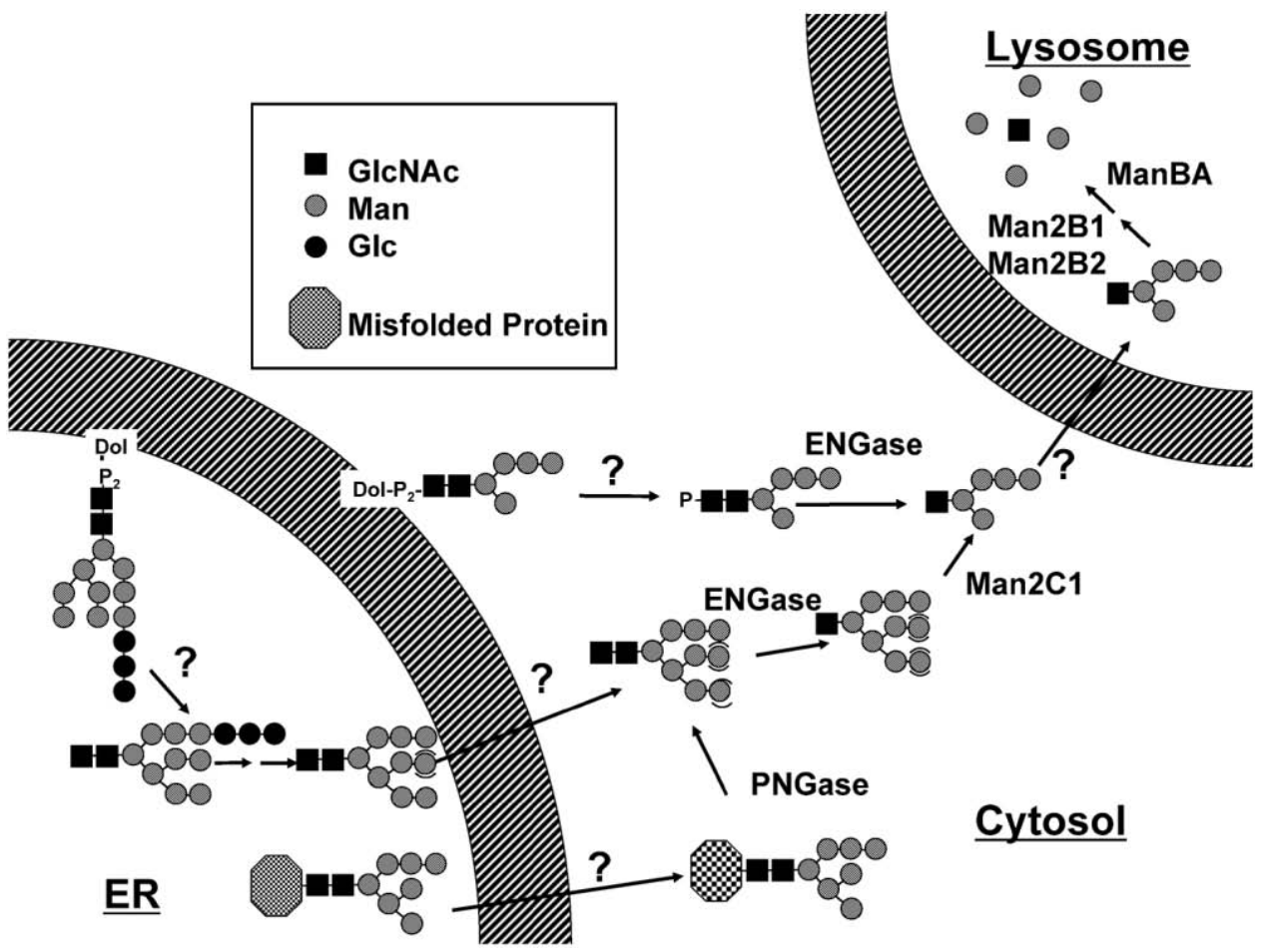

Fig. 2. Degradation of free $N$-glycans generated in and out of the ER in mammalian cells (9). Note that this scheme may not be applicable for cells derived from different organisms. Molecular mechanism of processes with question marks remained unclarified. PNGase, peptide: $N$-glycanase; ENGase, endo- $\beta$ - $N$-acetylglucosaminidase; Man2C1, cytosolic $\alpha$-mannosidase; Man2B1, Man2B2, lysosomal $\alpha$-mannosidases; ManBA, $\beta$-mannosidase. 
(22). At any rate, the clarification of molecular mechanism of the non-lysosomal $\mathrm{N}$-glycan catabolic events will be the main theme of our laboratory for the time being. Surely such projects require a lot of courage, and even this "postgenome" era requires the establishment of a novel assay method, as well as tedious biochemical purification of proteins. Only the pure curiosity and the ambition to be the first to reveal the nature of totally unknown protein will be able to conquer such tough problems. If you believe you are the right personnel for this kind of task, do NOT waste any time and contact me right now $(-)$.

\section{Metabolism of Glycans and Comparative Glycobiol- ogy}

As I briefly overviewed the degradation process of $N$-glycans, we should realize that as little as we know about the process in mammalian cells, situation is much, much worse in non-mammalian organisms such as plants, insects, and even yeasts. With respect to the nonlysosomal degradation of $\mathrm{N}$-glycans, for instance, while PNGase is conserved throughout eukaryotes, ENGase does not exist in some yeast, and Man2C1 is only conserved in vertebrate (19-21). These facts clearly tell us that the scheme presented in Figs. 1 or 2 cannot be applied to other organisms. Of course same can be said for biosynthesis of $N$-glycans, but the situation is far more serious for the case of the degradation pathway, since there are too many issues left unexplored. For example, while there are reports about comparative genomics for glycosyltransferase genes through bioinformatics approach $(23,24)$, similar approach has not been taken for glycosidases (except for the ones involved in biosynthetic pathway). Here is another example; among the $\alpha$-mannosidase-like genes found in D. melanogaster genome, apparent orthologues in mammalian cells could not be found for as much as 8 genes $^{* 1}$, all of which are still left uninvestigated. I thus believe, as pointed out previously (25), that we need to understand the difference between organisms to unveil the whole picture of glycan metabolism. Examples of plant endo- $\beta$-mannosidase $(26,27)$ or processing $\beta$-hexosaminidase in insects $(28,29)$ are some proofs to convince us that it is impossible to understand everything by just studying the metabolic pathway in mammalian cells.

\footnotetext{
*1 Yoko Funakoshi and Tadashi Suzuki, unpublished observation. Note that some of these 8 genes may be pseudogenes.
}

(22)。いずれにしても細胞質の出来事を中心とした非リソ ソーム $\mathrm{N}$ 型糖鎖の代謝, 分子機構の解明はもちろん我々の研 究室のメインテーマであるが，このポストゲノムの時代にお いても新しいアッセイ系や, 酵素の生化学的な精製が必要で あり，行く手には様々な困難が待ち受けていることが予想さ れる。この困難を克服する術は, 全く未知の酵素を世界で初 めて明らかにする，という知的好奇心と野心以外にはないと 信じている。その研究の醍醐味をどっぷりと味わいたいとい う人は，是非私まで連絡を下さい。

\section{D. 糖鎖代謝と比較生物学}

以上非常に簡単に糖鎖の分解について概観してみたが, ここで気づくことは, 糖鎖の分解の知識の殆どが哺乳動物の ケースに限定されるが, 植物や昆虫, 酵母などでは全く違う 経路が㗢いていることが予想されることである。たとえば我 々が見出した非リソソーム酵素に関しては, PNGase は殆ど の真核生物に保存されているが, ENGase は酵母などには存 在せず，細胞質マンノシダーゼ Man2C1 にいたっては脊椎動 物でのみ保存されているようである(19-21)。このことから も，図 1，2 に示したようなスキームは実は糖鎖の代謝のほん の一面に過ぎないことに気づかされる。

もちろんこういった比較生物学的検討の必要性は生合成 経路でも同じことが言えるのであるが，知識が哺乳動物に偏 っているという点では分解の系がより顕著であると思われる し, 分析がかなり立ち遅れていると強く感じられる。たとえ ば，糖転移酵素に関してはバイオインフォマティクスによる 比較生物学的検討がされている一方で $(23,24)$, グリコシダー ゼといった分解系の酵素については（糖鎖生合成のプロセシ ングに関わる酵素を除いては）殆ど検討されていない，とい う事実からも明らかであらう。また，たとえばショウジョウ バエではゲノム情報からマンノシダーゼ様遺伝子が数多く存 在していることが知られているが，そのうち（偽遺伝子であ る可能性を含めて）哺乳動物のマンノシダーゼとオルソログ 対応がとれていない遺伝子が 8 つ存在する（船越抢よび鈴 木調べ)。やはり以前より指摘されてきている通り $(25)$, 生物 に抢ける糖鎖の代謝機構を把握するには，様々な種における 違いがあることも理解しておくことが重要であると思われ る。たとえば植物のエンドー $\beta$-マンノシダーゼ $(26,27)$ や, 昆 虫にあるプロセシングに関わるへキソサミニダーゼ $(28,29)$ な ど, 種特異的と思われるグリコシダーゼの存在は, 少なくと も糖鎖の代謝というものが哺乳動物から得られた知識だけで 説明のつくものではないことを如実に物語っている。 


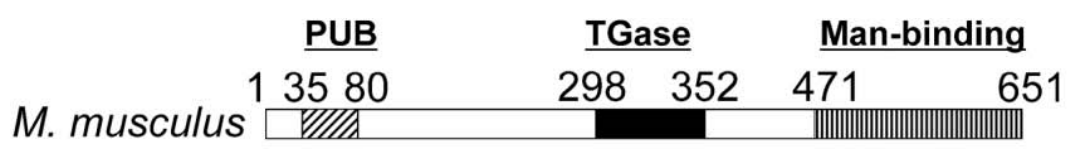

\section{Thioredoxin}

C. elegans

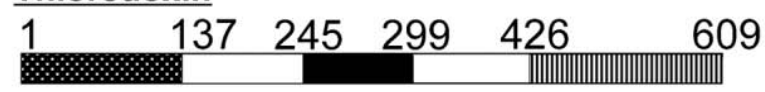

A. thaliana

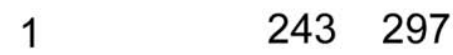

721

S. cerevisiae

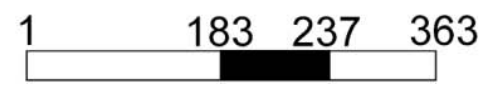

Fig. 3. Schematic representation of the primary structure of orthologues of the cytoplasmic PNGase. PUB, protein-protein interaction domain found in PNGase orthologues from vertebrates and fly (41). TGase, transglutaminase domain essential for PNGase activity. Man-binding, a domain recently identified as a mannose-binding module (42). Such diverse structural variations between species are clearly the outcomes of evolution, but their biological meaning remains unclarified.

\section{E. Other unanswered questions}

I started my career as a scientist with an undergraduate research at Prof. Yasuo Inoue's lab. Back then, my initial research theme was "an attempt to search for the novel PNGase activity in mammalian cells and tissues". Details of my early works were described elsewhere $(6,10,30)$, but in any case biological function of PNGase is still top of the list of my research interest. The cytoplasmic PNGase is, indeed, a truly intriguing enzyme, and while the genes are conserved throughout eukaryotes, their primary structures are quite distinct from species to the other (Fig. 3). In one example, it is interesting to note that according to the recent report plant PNGase has a transglutaminase activity (31), besides its deglycosylation activity (32). Because the cytoplasmic PNGase belongs to the transglutaminase superfamily (33), the fact that PNGase possesses TGase activity might not sound so surprising. However, the PNGase orthologues in yeast were clearly shown not to have a TGase activity (34), and taking the structural diversity into account, it can be easily envisaged that this protein follows a quite distinct evolutional route between yeast and plants. We are now investigating the biological roles of PNGase orthologues using various models such as mice, flies, and plants. Although we have encountered interesting number of phenotypic consequences due to the deletion/mutation of PNGase orthologue genes in these organisms, we have a sneaking suspicion that, whatever phenotypes we are seeing, we should carefully evaluate whether deglycosylating activity or other enzyme activities are responsible for them. It is even possible that the phenotypes are nothing to do with its en-
E. その他, 明らかにすべきこと

さて，私の研究者人生は学部学生の時に “哺乳動物中の PNGase 活性探し”というテーマを与えられたところから全 てが始まっている。その経緯の詳細は他稿に譲るが $(6,10,30)$, 今でも PNGase の生理機能というのは最も興味の あるトピックスのひとつである。この酵素は進化的にも非常 に興味深い酵素であり, 酵母からヒトまで広く保存されてい るものの, その構造は非常に異なっている。たとえば植物で はPNGase の活性を持つ(31) という報告以外にトランスグル タミナーゼ（TGase）活性を持つ，という報告もある(32)。 PNGase は TGase スーパーファミリーに属する酵素であり (33)，その意味で PNGase が TGase 活性を持つこと自体は不 思議なことではないが，実際酵母の PNGase では TGase 活性 は存在しない, とされており (34), 分子の構造の違いも考え 合わせると本タンパク質は進化的に異なる性質を獲得してき たことは容易に想像できる。我々は現在マウス，ショウジョ ウバエ，そしてシロイスナズナに括ける PNGase オルソログ の機能研究を行っているが，その表現型については脱糖鎖の 酵素活性に依存するものなのか，また別の酵素活性によるの か，更には酵素活性とは全く無関係な生理活性によるのか， といった問題は今後慎重に検討されるべき, という感触を得 ている。少なくとも PNGase は脱糖鎖酵素で, それが本タン パク質の全ての生理活性につながっているという根拠なき予 断は慎むべきである。

一方で $\mathrm{N}$ 型糖鎖における非リソソーム代謝においても,

図 2 のように図示してしまうとかなりのことが分っているか のような錯覚に陥るが，決して全てのことが明快にされてい 
zymatic activity. At least we should not blindly assume that all the phenotypes are due to the lack of deglycosylation activity.

With respect to the non-lysosomal degradation pathway for $N$-glycans, by depicting the figures like Fig. 2 we may fall into a wrong idea as if we know most of it, but we should realize that even in this scheme there remain many questions still to be clarified. For example, does ENGase really work only towards free $N$-glycans? Theoretically, this enzyme can also act on other glycoconjugates such as $\mathrm{N}$-glycoproteins or dolichol-linked oligosaccharides. Therefore such a possibility should not be negated unless examined intensively. Another example is, how exactly free $\mathrm{N}$-glycans are incorporated into the lysosomes? Right now the occurrence of free oligosaccharide transporter on the lysosomal membranes has been reported $(35,36)$, but whether there is an alternative path remains to be examined. Of course, it should be noted that the scheme presented in Fig. 2 is only for high-mannosetype glycans, and degradation pathway for complex type free glycans, which are also reported in the cytosol of mammalian cells and tissues $(37,38)$, is very poorly understood. Moreover, I frankly wonder if anyone has ever seriously examined whether there is any non-lysosomal degradation pathway for other type of glycans, such as mucintype $O$-glycans (exception is the recent paper by Dr. Ito's group about the finding of neutral $\beta$-glycosylceramidase, which could be involved in a novel nonlysosomal catabolic pathway of glucosylceramide (39)). Taking all the facts into consideration, it won't be surprising that, after 10 years, Figures in this review may be extensively revised. However, certainly there are a lot to be explored, and it is not a bad sign for us. I therefore feel that it is absolutely necessary that, not only our group, but also many researchers should join in this unexplored research field and constantly scrutinize and revise the current model.

\section{F. Epilogue}

As I mentioned earlier, progress in glycobiology has been extraordinarily intense over the past decade, and we have witnessed that genes after genes involved in the biosynthesis of glycans have been cloned during that period (to add a little note, Japanese scientists made a great contributions on this gene-fishing). However, I still feel that we have not yet reached to the point that we can say that "well, we understand the functions of glycans!!". There are numerous reasons for that, but I just would like to emphasize here that we still miss significant chunks of knowledge on degradation machinery of glycans, including that of $\mathrm{N}$-glycans, even more so than that on biosynthesis. In this regard, recently Dr. Taniguchi presented an
るわけではないことを強調しておきたい。たとえば，ENGase は遊離糖鎖にしか働いていないように見えるが，本当にそう なのか？もちろんタンパク質やドリコールに結合した糖鎖 も理論的には基質とし得るわけだが，そのような可能性が全 くないか，ということは予断なく検討される価值のある問題 と思われる。また，糖鎖のリソソームへの取り込みは現在卜 ランスポーターによる取り込みが生化学的に知られているが $(35,36)$, 他の経路は存在しないのか, たとえば細胞外に放出 したり，別の経路でリソソームにターゲットするような経路 の存在がないのかどうか, ということも真剣に検討が必要で あろう。もっといえば, ここに記されている経路は高マン ノース型糖鎖に関してのみのことであり,これまで時々見ら れているような複合型の遊離糖鎖の分解経路 $(37,38)$ などは全 く不明といっていい。まして，これが $\mathrm{N}$ 型糖鎖以外という話 になれば，非リソソーム代謝経路があるのか，といったこと さえこれまで真面目に検討されていないのではなからうか (この点, 最近の伊東先生のグリコシルセラミドの分解に関わ るかもしれない細胞質酵素についての報告は非常に興味深い (39))。このようなことも含めて, 今後 10 年で現在この総説 に書かれている図が一変する事態も充分考光られるが，それ はこの分野に携わるものとしては非常に嬉しい悲鳴である。 大事なことは, 我々だけでなく, 多くの研究者によってこの 経路が検討され，より正しいモデルを提唱する努力をするこ とであると強く感じる。

F. おわりに

最初で述べたように，ここ10 数年での糖鎖生物学の進歩 は目覚しく, 生合成に関わる遺伝子が次々と明らかにされて きたことは我々の記憶にも新しい（そして，その多くの部分 が日本発の研究, あるいは日本が多大な貢献をしてきたこ々 については周知の通りである)。しかしながら, 我々はまだを だ糖鎖の生理機能を多くの場合に打いて把握しているにいた っていない。その理由は一つではないが, 確実にいえること は我々は “糖鎖の代謝 “に対する知識が（生合成のそれに比 べて）著しくかけている，ということである。最近谷口先生 が “糖鎖サイクル”という概念を発表されて抢り (40), 糖鎖 の構造の変化を単に生合成からだけでなく, より多様な因子 
intriguing concept of "glycan cycle" (40), which basically claims that changes of glycan structures should be assessed in the context of not only changes of glycosyltransferases but also other factors, such as concentration of nucleotide sugars, not to mention the changes of degradation rates. The word "glycometabolome"' in the title is a coinage, but we should keep in mind that metabolism is, in an original sense, a set of processes which consists of two basic types of interdependent phases called anabolism (synthesis) and catabolism (degradation). Therefore, understanding the "life of glycans" from biosynthesis to degradation is the ultimate goal for glycometabolome. Let aside differences between species, we must face the reality that it is going to be a long, long way to get there. But again, it is still not discouraging news for scientists. Rather I would like to take this as a huge chance for us, since there are countless interesting questions awaiting us to be solved. I have been really fortunate to organize a new research team in RIKEN Advanced Science Institute, in order to tackle those interesting issues with very talented young scientists (well, I still consider myself young, as far as I am concerned). Although my main focus is still on clarifying the mechanism of non-lysosomal $\mathrm{N}$-glycan degradation pathway, I would also like to give a down-to-earth effort towards comprehensive understanding of the metabolism of $\mathrm{N}$-glycans and $N$-glycoproteins, including their biosynthesis and intercellular transport.

\section{Acknowledgements}

All of my research, up until now, stems from the theme given to me when I joined the Prof. Yasuo Inoue's laboratory as an undergraduate student in 1991. I would like to express my sincere gratitude to late Prof. Yasuo Inoue and his wife, Prof. Sadako Inoue, for their continuous encouragements from the very beginning of my research career. Despite my notorious reputation as a devoted musician back then, they accepted me as their student and never complained about my behavior, at least not to my face. They showed me how to take the first right step to enter this wonderful world of science and how to really enjoy it. I also express my special thanks to Prof. Ken Kitajima (Nagoya University) and Dr. Akira Seko (Tokyo Institute of Technology), who very patiently taught experimental techniques from the very basic to this pathetic musician-scientist-wannabe. I would not have been who I am without their guidance, which I am very grateful. I also would like to express my sincere gratitude to Prof. Yasufumi Emori, who accepted me in his lab after Prof. Inoue's retirement, and taught me protein purification and molecular biology. He also made my return to Japan possible, which I deeply appreciate. I also would like to ex-
の中で捉える必要がある，ということを主張されている。だ とすれば，当然糖鎖の代謝の影響も充分考慮にいれる必要が あることは自明であろう。タイトルの“glycometabolome” と いう言葉はもちろん造語であるが，“Metabolism”は本来 “Anabolism”と“Catabolism”を合わせた意味をもつ。その 生合成から分解丈で，糖鎖の“一生”を把握してこそ metabolismの分子機構を初めて理解したことになり，先に述 べたと拈り種による違いをも考慮すれば，まだまだその全容 解明への道のりは遠い。そのこと自体はがっかりすることで もなく, むしろ未知の興味ある課題が山積している, という のは研究者にとっては喜ばしい事態といえるのではないだろ うか。

現在理化学研究所で優秀な若い研究者の参画を得て, こ れらの問題のいくつかにチャレンジできる幸運に恵まれた （自分もまだまだ若いつもりではいるが）。気負わず，まずは 糖鎖の代謝に軸足を置きつつ, 将来的には生合成, 細胞内輸 送などを含めた糖タンパク質の動態変化, 更はその変化をコ ントロールする方法についての可能性の追求など, 自分の興 味深いと思った研究テーマにも果敢にチャレンジしていこう と考えている。

謝辞 :

私の研究はいうまでもなく井上研で与えられたテーマに 端を発して抢り, 故井上康男先生, そして奥様の井上貞子先 生には研究の最初から変わらぬ叱咤激励をいただきました。 研究室に配属当事, 音楽にのめりこんでいた私を両先生に暖 かく見守っていただいたおかげで, 研究という一生モノの旅 路の最初の一歩を楽しく踏久出すことが出来ました。本当に 感謝申し上げます。また, 北島健先生, 瀬古玲先生にはスチ ヤラカ学生だった私に根気強く実験のイロハを指導していた だきした。この両先生の忍耐と指導なくしては現在の私は ありえません。改めて深く感謝申し上げます。私の博士論文 の指導者を榎森康文先生は引き受けてくださり, タンパク質 の精製と分子生物学の基礎についてご指導いただき，また留 学後日本に帰ってくるきっかけを作っていただきました。心 から感謝申し上げます。ポスドク時代の指導者であった Stony Brook 大学の William J. Lennarz 先生, さきがけ研究の総括 であった永井克孝先生, 大阪大学 $\mathrm{COE}$ の代表であった谷口直 之先生には, 私の研究に強力な経済的支援と, 何より必要な 研究テーマ選択の自由を与えてくださいました。心から感謝 申し上げます。また, 私の研究は多くの共同研究者の支えに 
press my sincere gratitude to my former mentors/advisors; Prof. William J. Lennarz (Stony Brook University); Prof. Yoshitaka Nagai (RIKEN); and Prof. Naoyuki Taniguchi (Osaka University/RIKEN), for giving generous support, and above all, the scientific freedom indispensable to my research. I also would like to appreciate all the encouragement and help given to me from many past and current collaborators. I also thank all the former and current members of my laboratory. Especially I would like to thank the current members, whose names are listed below, out of my appreciations for their enthusiasm and help, which enable me to live a full life in the current lab; (in an alphabetical order) Dr. Yoko Funakoshi , Dr. Yoshimi Haga, Dr. Hiroto Hirayama, Dr. Akira Hosomi, Ms. Kumiko Ishii, Ms. Yuki Negishi, Mr. Junichi Seino, Ms. Yae Tsuchiya, Ms. Kotoko Ueno, and Dr. Li Wang.

At last, but not the least, I would like to thank my wife, Miki, for editing my English. Of course English editing is really trivial compared to how much I need to thank her for everything, but I feel that everyone should note that, if my English is somehow better than ordinary, then it is all thanks to her editing. For this article, because I did not get her editing on this paragraph, I am afraid that the readers may pick up the difference.

The work of Glycometabolome Team was partly supported by the Global COE (Center of Excellence) Program, Osaka University.
よって成り立っています。多くの方々のご協力と熱意に深く 御礼申し上げます。そして私の研究室に在籍した過去, そし て現在のメンバーの協力に心から感謝申し上げをす。特に現 メンバーには, 日々の活発な議論を始め, また陰で研究室の 運営を支えてくださり，非常に充実した日々を過ごさせてい ただいていることに深く感謝をし，打名前を記します（アル ファベット順です）：船越陽子さん，芳賀淑美さん，平山弘人 君, 細見昭君, 石井久美子さん, 根岸由紀さん, 清野淳一 君, 土屋八恵さん, 上野琴子さん, 王麗さん。

最後に私の英語をいつも添削してくれる妻の美希に感謝 します。もちろん感謝といえば，妻には日ごろの全てに対し て深く（×100）感謝しなくてはいけないことは言うまでもな いのですが，以前ある先生から“鈴木の論文の英語は格調が 高い”という㧍倠めの言葉を頂いたことがあるのですが，も しそれが事実だとすれば一重に彼女の打陰であることを彼女 の名誉のために申し添えます（この段落だけ彼女の校閲をう けていませんが，格調の違い（？)分分ってしまうことを私は 恐れています)。

尚当研究室の研究の一部はグローバル COE プログラム (大阪大学)によってサポートされてい屯す。

\section{References}

1. Takahashi, N. (1977) Biochem. Biophys. Res. Commun. 76, 1194-1201

2. Plummer Jr., T. H., Elder, J. H., Alexander, S., Phelan, A., W., and Tarentino, A. L. (1984) J. Biol. Chem. 259, 10700-10704

3. Seko, A., Kitajima, K., Inoue, Y., and Inoue, S. (1991) J. Biol. Chem. 266, 22110-22114

4. Suzuki, T., Seko, A., Kitajima, K., Inoue, Y., and Inoue, S. (1993) Biochem. Biophys. Res. Commun. 194, 1124-1130

5. Suzuki, T., Seko, A., Kitajima, K., Inoue, Y., and Inoue, S. (1994) J. Biol. Chem. 269, 17611-17618

6. Suzuki, T., Park, H., and Lennarz, W. J. (2002) FASEB J. 16, 635-641

7. Suzuki, T. and Lennarz, W. J. (2003) Biochem. Biophys. Res. Commun. 302, 1-5

8. Suzuki, T. (2005) Methods 35, 360-365

9. Suzuki, T. (2007) Sem. Cell Dev. Biol. 18, 762-769

10. Suzuki, T. (2003) Seikagaku 75, 1405-1413

11. Suzuki, T. (2006) Seikagaku 78, 1123-1130

12. Aronson Jr., N. N., and Kuranda, M. J. (1989) FASEB J. 3, 2615-2622

13. Winchester, B. (2005) Glycobiology 15, 1R-15R

14. Song, Z. W., Li, S. C., and Li. Y. T. (1987) Biochem. J. 248, 145-149

15. Fisher, K., J. and Aronson Jr., N. N., (1992) J. Biol. Chem. 267, 19607-19616

16. Park, C., Meng, L., Stanton, L. H., Collins, R. E., Mast, S. W., Yi, X., Strachan, H., and Moreman, K. W. (2005) J. Biol. Chem. 280, 37204-37216

17. Suzuki, T., Yan, Q., and Lennarz, W. J. (1998) J. Biol. Chem. 273, 10083-10086

18. Suzuki, T., and Funakoshi, Y. (2006) Glycoconj. J. 23, 291-302

19. Suzuki, T., Park, H., Hollingsworth, N. M., Sternglanz, R., and Lennarz, W. J. (2006) J. Cell Biol. 149, 1039-1052

20. Suzuki, T., Yano, K., Sugimoto, S., Kitajima, K., Lennarz, W. J., Inoue, S., Inoue, Y., and Emori, Y. (2002) Proc. Natl. Acad. Sci. USA 99, 9691-9696

21. Suzuki, T., Hara, I., Nakano, M., Shigeta, M., Nakagawa, T., Kondo, A., Funakoshi, Y., and Taniguchi, N. (2006) Biochem. J. 400, 33-41

22. Funakoshi, Y., and Suzuki, T. (2009) Biochim. Biophys. Acta 1790, 81-94

23. Baerjee, S., Vishwanath, P., Cui, J., Kelleher, D. J., Gilmore, R., Robbins, P. W., and Samuelson, J. (2007) Proc. Natl. Acad. Sci. USA 104, 11676-11681

24. Hashimoto, K., Tokimatsu, T., Kawano, S., Yoshizawa, A. C., Okuda, S., Goto, S., and Kanehisa, M. (2009) Carbohydr. Res. 
in press (doi:10.1016/j.carres.2009.03.001)

25. Natsuka, S. (2005) Trends. Glycosci. Glycotechnol. 17, 229-236

26. Ishimizu, T., Sasaki, A., Okutani, S., Maeda, M., Yamagishi, M., and Hase, S. (2004) J. Biol. Chem. 279, 38555-38562

27. Ishimizu, T., and Hase, S. (2006) Trends Glycosci. Glycotechnol. 18, 39-47

28. Altmann, F., Schwihla, H., Staudacher, E., Glossl, J., and Marz, L. (1995) J. Biol. Chem. 270, $17344-17349$

29. Leonard, R., Rendic, D., Rabouille, C., Wilson, I. B., Preat, T., and Altmann, F. (2006) J. Biol. Chem. 281, 4867-4875

30. Suzuki, T. (2006) Functional Glycomics News Letter (No. 7) pp36-40

31. Diepold, A., Li, G., Lennarz, W. J., Nurnberger, T., and Brunner, F. (2007) Plant J. 52, 94-104

32. Dela Mea, M., Caparros-Ruiz, D., Claparols, I., Serafini-Frascassini, D., and Rigau, J. (2004) Plant Physiol. 135, 2046-2054

33. Makarova, K. S., Aravind, L., and Koonin, E. V. (1999) Protein Sci. 8, 1714-1719

34. Iranzo, M., Aguado, C., Pallotti, C., Canizares, J. V., and Mormeneo, S. (2002) Microbiology 148, 1329-1334

35. Saint-Pol, A., Bauvy, C., Codogno, P., and Moore, S. E. H. (1997) J. Cell Biol. 136, 45-59

36. Saint-Pol, A., Codogno, P., and Moore, S. E. H. (1999) J. Biol. Chem. 274, 13547-13555

37. Ohashi, S., Iwai, K., Mega, T., and Hase, S. (1999) J. Biochem. (Tokyo) 126, 852-858

38. Ishizuka, A., Hashimoto, Y., Naka, R., Kinoshita, M., Kakehi, K., Seino, J., Funakoshi, Y., Suzuki, T., Kameyama, A., and Narimatsu, H. (2008) Biochem. J. 413, 227-237

39. Hayashi, Y., Okino, N., Kakuta, Y., Shikanai, T., Tani, M., Narimatsu, H., and Ito, M. (2007) J. Biol. Chem. 282, 30889-30900

40. Taniguchi, N. J. Biol. Chem., in press

41. Suzuki, T., Park, H., Till, E. A., and Lennarz, W. J. (2001) Biochem. Biophys. Res. Commun. 287, 1083-1087

42. Zhou, X., Zhao, G., Truglio, J. J., Wang, L., Li, G., Lennarz, W. J., and Schindelin, H. (2006) Proc. Natl. Acad. Sci. USA 103, $17214-17219$

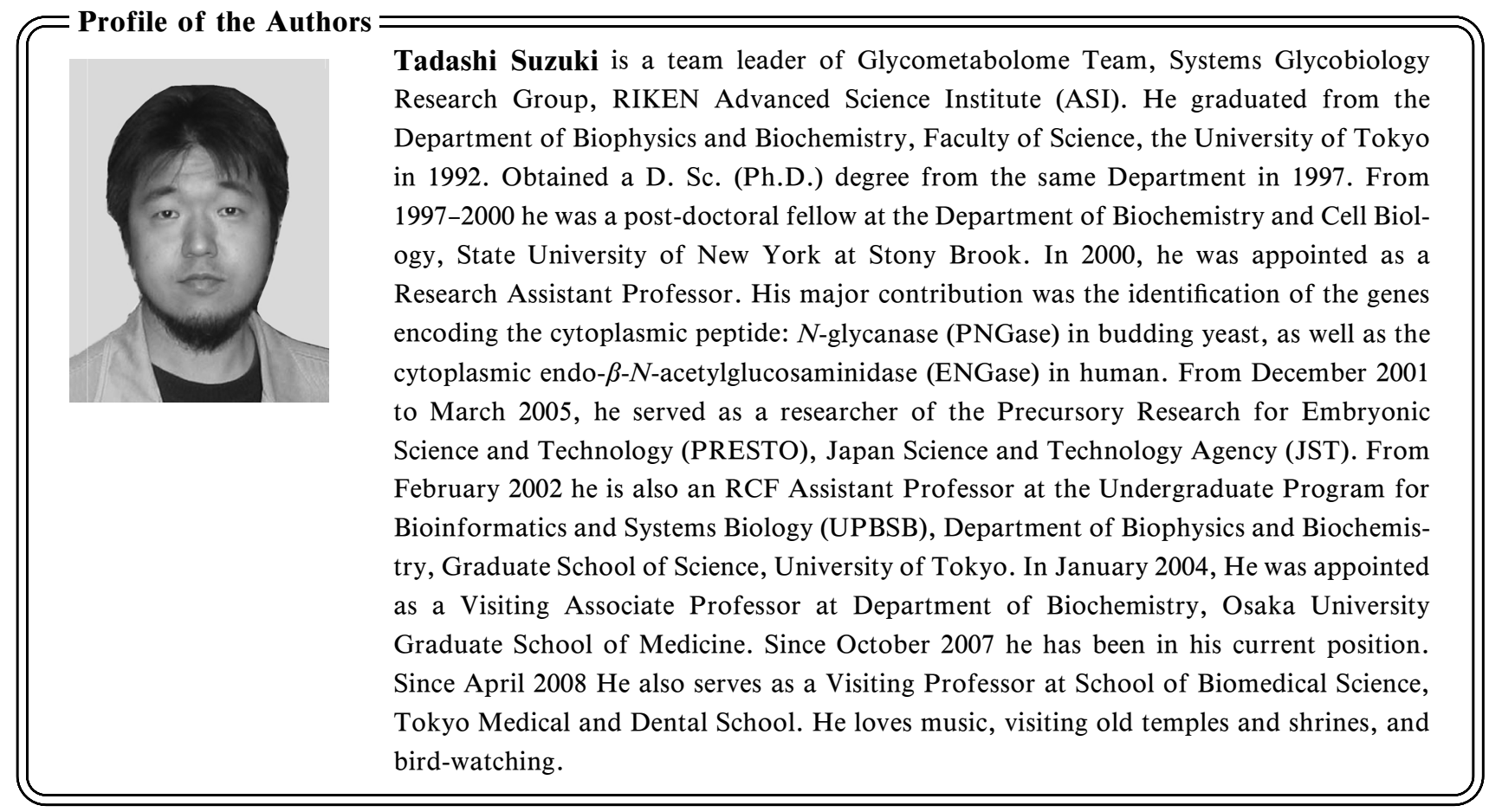

